\title{
Obituari
}

\section{Jesús Marcos Alonso (1930-1994)}

Josep M. Masjuan i Codina

Universitat Autònoma de Barcelona. Departament de Sociologia

08193 Bellatera (Barcelona). Spain

Val la pena des de les pàgines de PAPERS retre un breu homenatge a Jesús Marcos Alonso, sociòleg, malauradament desaparegut a mitjan febrer de 1994.

En Jesús Marcos va contribuir molt decisivament a la primera institucionalització de la sociologia a Barcelona cap a la meitat dels anys seixanta. Va ser el primer professor de Teoria Sociològica a l'Escola EISA, centre privat a manera de fundació que pretenia suplir la manca d'estudis universitaris de ciències socials des d'una perspectiva crítica al règim franquista. Posteriorment va dirigir el Departament de Sociologia de l'ICESB des de 1970 fins a 1982. No era facil trobar sociòlegs en aquells moments i els estudiants de l'època li estem agraïts.

La seva activitat en el terreny de la recerca ha estat molt rica; s'ha dedicat principalment a tres camps:

a) La sociologia de les professions. Són nombrosos els treballs fets sobre diferents aspectes de les professions tècniques, sobretot com a membre de la revista $C A U$ del Col.tegi d'Aparelladors i del Gabinet d'Estudis del Col.legi Oficial d'Enginyers Industrials de Catalunya. Potser val la pena destacar els dos primers treballs realitzats els anys setanta sobre la professió d'aparellador i d'enginyer industrial —ambdós publicats - perquè signifiquen, a parer meu, una aportació a la sociologia del moment, que encara en manté el valor. Són un exponent de la seva manera de treballar ja que, fugint de l'aplicació mecànica d'alguns dels paradigmes vigents a l'època, aconsegueix un plantejament $i$ una recerca prou originals $i$ interessants.

b) La sociologia de la sanitat. En aqtest camp m'agradaria destacar la seva contribució al treball interdisciplinari ja que la majoria d'obres, moltes d'elles publicades, responen a la seva tasca de direcció i coordinació de grups de professionals del camp de la salut, realitzada en el marc del Col.legi de Metges. Treballs sobre temàtica diversa com el metge de cap̧̧alera, els centres de salut, les necessitats de personal mèdic etc. Darrerament era director d'una publicació científica en el camp de la ciència de la salut publicada per CAPS (Centre d'anàlisi de programes sanitaris). 
c) La sociologia de l'esport. Des de l'Àrea d'Esports de l'Ajuntament de Barcelona, on també treballava, va dirigir una macroenquesta sobre el comportament esportiu dels barcelonins, de la qual s'han publicat diferents aspectes parcials.

Els que el vam conèixer i estimar en vam aprendre unes quantes qualitats ben envejables: independent de criteri i molt rigorós, mai no afalagava ningú per obtenir alguna cosa a canvi, i tenia davant de les idees i els fets un cert distanciament crític, expressió de la seva maduresa intel.lectual. Al mateix temps era un home bo. 